\title{
The changes made in the article titled "BIOCHEMICALANALYSIS FOR NEUROPROTECTIVE EFFECTS OF GANODERMA LUCIDUM IN EXPERIMENTAL RAT SPINAL CORD TRAUMA MODEL" in the original articles section published in JTSS 2021 32(3) are as follows.
}

J Turk Spinal Surg 2021;32(3):116-22

DOI: $10.4274 /$ jtss.galenos.2021.99608

Some corrections have been requested by the author of the article in the Copyright form of the article numbered 99608 published in the 3rd issue of the Journal of Turkish Spinal Surgery 2021 and within the article."

The corrected sections are listed below.

- The author named "Sevgi Akaydın" and her signature have been added to the 8th line among the authors in the Copyright form.

- The list of author names on the first page of the article is replaced by “Denizhan Divanlıoğlu, Ece Miser Salihoğlu, Murat Korkmaz, Ahmet Eren Seçen, Özgür Öcal, Göksal Günerhan,A. Deniz Belen, Sevgi Akaydın, Ali Dalgıç” instead of “Denizhan Divanlıoğlu, Ece Miser Salihoğlu, Murat Korkmaz, Ahmet Eren Seçen, Özgür Öcal, Göksal Günerhan, A. Deniz Belen, Ali Dalgıç". The institution information of the added author is the same as the other authors. No changes have been made to the institution information.

- The order in the "Author Contributions" section on page 120 of the article is arranged as "Design: D.D., E.M.S., M.K., D.B., S.A., A.D., Data Collection or Processing: D.D., E.M.S., M.K., G.G., S.A., D.B., A.D., Analysis or Interpretation: D.D., E.M.S., A.E.S., Ö.Ö., G.G., S.A., D.B., A.D., instead of, “Design: D.D., E.M.S., M.K., D.B., A.D., Data Collection or Processing: D.D., E.M.S., M.K., G.G., D.B., A.D., Analysis or Interpretation: D.D., E.M.S., A.E.S., Ö.Ö., G.G., D.B., A.D.,." 